Інноватика у вихованні. Випуск 12. 2020.

УДК 373.2.091.33

DOI: $\underline{10.35619 / \text { iiu.v1i12.308 }}$

Козак Людмила

доктор педагогічних наук, доцент, професор кафедри дошкільної освіти Київського університету імені Бориса Грінченка, м. Київ, Україна,

ORCID: 0000-0002-4528-1905 e-mail:l.kozak@kubg.edu.ua

\title{
ХАРАКТЕРИСТИКА СУЧАСНИХ ФОРМ ОРГАНІЗАЦЇ̈ ОСВІТНЬОГО ПРОЦЕСУ В ЗАКЛАДАХ ДОШКІЛЬНОЇ ОСВІТИ
}

\begin{abstract}
Анотація. У статті висвітлено актуальні питання використання сучасних форм організації освітнього процесу в закладах дошкільної освіти; встановлено, що освітній процес в умовах закладу дошкільної освіти - це цілісний процес взаємодії дорослих і дітей, який розвивається в часі та просторі в межах певної системи i спрямований на досягнення соціально-значущих результатів набуттю життєвої компетентності, розвитку базових якостей особистості в різних видах діяльності; доведено, що сучасний освітній процес характеризується інтегративністю, проблемно-ігровою спрямованістю, передбачає пізнавальне спілкування вихователя і дітей, самостійність дітей і особистісно орієнтований підхід педагога; наголошено на доцільності організації освітньої діяльності з дітьми дошкільного віку у формі педагогічного спілкування в колі, різних видів занять, освітніх ситуацій та подорожей, тематичних проєктів, прогулянок, екскурсій, дослідницько-пошукової діяльності, ігор, гурткової роботи, продуктивної праці, самостійної діяльності дітей відповідно до завдань фізичного, соціального, комунікативного, пізнавального та художньо-естетичного розвитку; проаналізовано наукові дослідження стосовно питань застосування сучасних форм організації освітнього процесу в закладах дошкільної освіти; розкрито зміст понять «освітній процес в умовах закладу дошкільної освіти», «форми організації освітнього процесу», «спілкування в колі», «сучасне заняття», «освітня ситуація», «освітня подорож», «проєктна діяльність», «колекціонування», «експериментування», «квест», «геокешинг», «ігри 3 вільними матеріалами», «гра-стратегія»; охарактеризовано особливості сучасних форм організації освітнього процесу в закладах дошкільної освіти; визначено форми, що найбільш використовуються в організації освітньої діяльності дошкільнят.

Ключові слова: форми організації освітнього процесу, освітня ситуація, освітня подорож, спілкування в колі, проєктна діяльність, колекціонування, експериментування, квест, геокешинг, гра-стратегія, ігри 3 вільними матеріалами.
\end{abstract}

Постановка проблеми. Сучасний етап модернізації дошкільної освіти в Україні потребує якісних змін в організації освітнього процесу, орієнтуючи педагогів на використання у своїй діяльності більш ефективних форм і методів

(С) Козак Л., 2020 
навчання та виховання дошкільнят. Це пов'язано 3 тим, що акцент в освіті зміщується на розвиток вільної, творчої особистості, здатної самостійно мислити, здобувати i застосовувати знання в різних життєвих ситуаціях, приймати обмірковані рішення і чітко планувати свої дії, а також ефективно співпрацювати з однолітками, бути відкритими до нових контактів і зв'язків.

Аналіз останніх досліджень 3 проблеми. Усвідомлюючи необхідність перебудови освітнього процесу, науковці та практики зосереджують увагу на пошуку оптимальних способів організації освітньої роботи 3 дошкільнятами, зокрема: інтегровані заняття (Н. Гавриш, І. Кіндрат, К. Крутій та ін.), освітні ситуації та подорожі (Т. Грицишина, К. Крутій, І. Стеценко), проєктна діяльність (Н. Гавриш, С. Ладивір, Т. Пірожено та ін.), пізнавальні прогулянки (Г. Бєлєнька, М. Машовець, О. Половіна та ін.), розвивально-пізнавальні ігри (Н. Гавриш, К. Крутій, Н. Рабчун, О. Стаєнна та ін.), експериментально-дослідна діяльність (Г. Бєлєнька, Л. Швайко та ін.). Пошук та впровадження в освітній процес нових форм і методів освітньої роботи $\epsilon$ справою нелегкою та довготривалою, а тому залишається актуальною для подальших досліджень.

Мета статті - висвітлити та охарактеризувати сучасні форми організації освітнього процесу в закладах дошкільної освіти.

Виклад основного матеріалу дослідження. Освітній процес у закладі дошкільної освіти - це цілісний процес взаємодії дорослих і дітей, який розвивається в часі та просторі в межах певної системи. Він спрямований на досягнення соціально-значущих результатів: набуття життєвої компетентності, розвитку базових якостей особистості в різних видах діяльності.

Сучасний освітній процес характеризується інтегративністю, проблемноігровою спрямованістю, передбачає пізнавальне спілкування вихователя і дітей, самостійність дітей і особистісно орієнтований підхід педагога (Козак, 2020).

Форму організації освітнього процесу розглядаємо як спосіб взаємодії 3 дітьми, який застосовує педагог з метою забезпечення конструктивного впливу різних методів і прийомів на розвиток особистості кожного вихованця.

Аналіз наукових публікацій та власний досвід дозволяє стверджувати, що організовану освітню діяльність з дітьми дошкільного віку доцільно проводити у формі педагогічного спілкування в колі, різних видів занять, освітніх ситуацій та подорожей, тематичних проєктів, прогулянок, дослідницько-пошукової діяльності, ігор, гурткової роботи, продуктивної праці, самостійної діяльності дітей відповідно до завдань фізичного, соціального, комунікативного, пізнавального та художньо-естетичного розвитку.

В освітньому процесі закладу дошкільної освіти провідним має стати спілкування дорослого $з$ дітьми (розповіді, тематичні бесіди, діалоги, полілоги тощо). Таке спілкування не регламентоване в часі і відбувається упродовж дня.

В основі педагогічного спілкування лежать різні види діяльності: комунікативна, ігрова, проєктна, еколого-природнича, здоров'язбережувальна, мистецька, побутова, суспільно-корисна праця тощо (Козак, 2020, с.356).

Досить ефективною формою $є$ спілкування в колі. Коло дає змогу налагодити соціальну взаємодію між дітьми й дорослими, зберегти й посилити енергію спільної творчої діяльності, сформувати повагу до чужої точки зору.

У колі педагог 3 дітьми може обговорювати майбутню діяльність, презентувати нові книги чи іграшки, поговорити про хвилюючі проблеми, спільно розробити правила взаємин. Кожне коло має свою тему, яка залежить від педагогічної ситуації. Тому коло можна розглядати як різноманітність кіл: 
коло створення емоційного настрою, концентрації уваги, психологічного комфорту - тут можна використовувати психологічні мікро тренінги, пропонувати ігрові вправи: кінезіологічні, на розвиток взаємодії та партнерства («Дзеркальне малювання», «Віддам тобі те, що є у мене» тощо);

коло отримання нових знань, розширення інформаційного поля дитини. У такому виді кола можна запропонувати дітям презентацію дидактичного матеріалу, розповісти історію, провести обговорення майбутнього проєкту або його завершення, заслухати повідомлення дітей;

рефлексійне коло дозволяє обмінятись новинами, розповісти про те, що хвилює; оцінити емоції, процес і результати діяльності тощо. Види рефлексійного кола - ранкове, вечірнє, понятійне («Яка користь від корисних звичок?», «Коли я щасливий?»), тематичне («Радість», «Доброта», «Краса»), подієве («День народження», «День матері», «День дошкілля» тощо).

Для всіх дітей важливою $є$ свобода вибору діяльності. Тому сьогодні однозначно слід відмовитись від застарілих підходів: суто фронтальних форм організації освітнього процесу, проведення класичних занять.

Слово «заняття», на думку Г. Бєлєнької, має залишитися лише у свідомості вихователя. Для дітей це просто спільна з дорослим діяльність, результатом якої $\epsilon$ нові знання й уміння. Дослідниця пропонує у розкладі занять замінити слово «заняття» такими визначеннями: «ігрові інтегровані заняття», «дослідження в природі», «формування рухів», «основи художнього мистецтва», «музичний розвиток» тощо (Бєлєнька, 2018, № 9, с. 2-6).

Сучасне заняття має бути цікавим для дітей, насиченим ігровими прийомами, елементами дослідження, розвивати пізнавальні здібності дітей, моральні та естетичні якості. Серед найбільш поширених форм проведення сучасних занять можна виділити пізнавально-розважальні ігри-заняття, заняттязмагання, заняття-пошуки, заняття-рольові ігри, заняття-драматизації тощо.

Не заперечуючи з погляду ефективності розвитку дошкільнят важливості занять, К. Крутій вважає за доцільне віддавати перевагу освітнім ситуаціям. Дослідниця розглядає освітню ситуацію як «ситуацію розумового напруження, що виникає спонтанно або спеціально організується вихователем, і розв’язання якої передбачає спільну діяльність усіх її учасників. Ї̈̈ мета полягає у створенні разом із дітьми певного освітнього продукту (результату)» (Крутій, 2016, № 9, c.7). Такі результати можуть бути як матеріальними (малюнок, саморобка, колаж), так і нематеріальними (ідея, ставлення, переживання).

У календарному плані вихователя варто передбачати вирішення освітніх cuтуацій з дітьми, починаючи з молодшого дошкільного віку. Наприклад, дітям четвертого року життя доцільно пропонувати розвиваючі освітні ситуації 3 гуманістичним змістом, такі як «Знайдемо друзів Цуценятку», «Зайченятко захворіло», «Допоможемо Ляльці одягнутися на прогулянку» тощо. При цьому будуть вирішені наступні завдання соціально-особистісного розвитку дітей: вміння дружити; допомагати іншому; розвинути культурно-гігієнічні навички та ін. Тривалість освітньої ситуації може бути від кількох хвилин до трьох і більше днів. Форми - групова, підгрупова, індивідуальна. Види - проблемні («Як 3'явилася веселка у небі»); дослідницько-пошукові («Як вода перетворюється на пару»); комунікативно-діалогові («Як ми святкували Новий рік»); ігрові («Як ми влаштуємо свято нашим лялькам»); практичні («Як ми садимо квіти на клумбі»). 
Цікавою і сучасною формою організації освітнього процесу в закладах дошкільної освіти є «Освітня подорож».

На думку дослідників, освітня подорож, як і освітня ситуація, може бути логічним втіленням спільної партнерської діяльності дорослого з дітьми (Крутій, Грицишина, Стеценко, 2017, №2, с.43-48).

Освітня подорож передбачає безпосереднє ознайомлення дошкільників 3 реальними або віртуальними об'єктами довкілля, що активізує діалогічну форму спілкування 3 однолітками та дорослими, а також розвиває навички дослідницької діяльності у дітей. Така подорож відрізняється від екскурсії тим, що передбачає початкову дослідницьку проблему, спрямовану на кінцевий результат, реальний продукт у вигляді нових знань, смислів, відображених у малюнках і схемах. Під час освітньої подорожі діти працюють із маршрутним листом (своєрідним путівником, який не лише вказує «шлях», а й охоплює питання і дослідницькі завдання, а також підказує способи дослідження).

У процесі освітньої подорожі поєднуються різні види діяльності дітей (спостереження, досліди, дослідження, пошук та аналіз інформації тощо).

Тематика подорожей залежить від віку дітей, їх інтересів та освітніх завдань: «Що росте на ділянці дошкільного закладу», «Транспорт нашого міста», «Мандруємо берегом Дніпра», «Подорож у світ казки» тощо.

3-поміж різних форм організації дитячої активності пріоритетною є проєктна діяльність (Козак, Коваль, 2020, № 71, Т.1, с. 129).

Проєктна діяльність - це створення педагогом таких умов, які дозволяють дітям самостійно або спільно 3 дорослим здобувати новий практичний досвід експериментальним, пошуковим шляхом, аналізувати його і перетворювати.

Метою дитячого колективу $\epsilon$ вирішення проблемної ситуації, пошук відповідей на актуальні питання, створення та презентація кінцевого продукту.

Реалізація будь-якого проєкту здійснюється в ігровій формі, із залученням дітей до різних видів творчої та практично значущої діяльності, в безпосередньому контакті 3 різними об'єктами соціального середовища (екскурсії, ігри, практично корисні справи). Проєкт може реалізовуватися в будь-якому об'єднанні дошкільників (у групі, підгрупі, одночасно в декількох групах, між декількома закладами, із залученням батьків дошкільників).

Надзвичайно важливою формою організації освітнього процесу в закладах дошкільної освіти, яка дозволяє поєднувати фізичну активність, емоційноестетичну та пізнавальну діяльність дошкільнят, є прогулянка.

Структурно прогулянка охоплює в себе: організацію 3 вихованцями спостережень за явищами природи; різноманітні ігри; експериментування; працю в природі; спортивні вправи; самостійну діяльність дітей за їх вибором. Основне завдання вихователя під час проведення прогулянки полягає в забезпеченні активної, змістовної та цікавої для дітей діяльності.

Беззаперечно, величезний розвивальний потенціал має експериментальна діяльність. Дитяче експериментування дозволяє успішно розвивати в них допитливість, активність, прагнення самостійно знаходити рішення проблем. Найцікавішими експериментами є реальні досліди зі справжніми предметами та їх властивостями (вода, пісок, лід, сніг, повітря тощо), які допомагають дитині пізнати суттєві ознаки природних об'єктів, рослинного світу.

Активне експериментування в образотворчій діяльності (вивчення властивостей різноманітних фарб, паперу тощо), музичній діяльності (дослідження утворення звуку в різних музичних інструментах тощо) та інших 
сферах діяльності допомагає дітям осмислити явища навколишнього світу, зрозуміти існуючі взаємозв'язки.

Серед інтересів дитини дошкільного віку чільне місце посідає колекціонування. Створення 3 дітьми різних колекцій сприяє реалізації завдань пізнавального розвитку: ознайомлення 3 навколишнім світом, розвиток навичок класифікації об'єктів за певними ознаками, уміння систематизувати інформацію тощо. А також допомагає налагодити ігрову та комунікативну взаємодії між педагогом і вихованцями. Вибір об'єктів для колекціонування має спиратися на вікові інтереси дітей та освітні завдання. Можна запропонувати дітям колекціонувати природні матеріали (камінці, листочки чи плоди дерев тощо), речі з минулого, та ін. (Терещенко, 2019, № 10, сс.30-31). Розумно організоване колекціонування виховує культуру пізнання, розвиває пізнавальні вміння, формує у дітей уявлення про значущість колекцій.

У дошкільному віці провідною формою діяльності є гра, тому їі необхідно найбільш ефективно використовувати в освітньому процесі.

Активізувати дитячу креативність, збагатити ігрову діяльність і розширити освітній простір без зайвих витрат, на думку Н. Гавриш, допоможуть ігри 3 вільними матеріалами. «Вільні матеріали» - це усілякі доступні дрібнички, невеликі однорідні предмети, наявні в довкіллі у великій кількості; природні й побутові матеріали (гудзики, стрічки, намистинки, мушлі, камінці, коробки, шишки, жолуді, палички тощо) (Гавриш, 2019, № 6 . с.9-13).

Дослідниця окреслює переваги «вільних матеріалів»: привабливість, відкритість, мобільність, економічна й екологічна доцільність та розвивальні можливості: створення умов для активного навчання; розвиток творчого мислення; фізичний соціально-емоційний та інтелектуальний розвиток.

Останніми роками великої популярності набувають ігри-квести. Це форма організації освітньої діяльності дітей, яка сприяє розвитку активної, дослідницької позиції дитини в ході вирішення ігрових пошукових завдань.

Квест - пригодницька командна гра, яка вимагає від учасників швидкого i якісного виконання проблемних завдань, об'єднаних спільним сюжетом з метою досягнення кінцевої цілі, у результаті чого гравець або команда отримує приз. Ідея гри проста: команди, переміщаючись точками, виконують різні завдання. Але особливість такої організації ігрової діяльності полягає в тому, що, виконавши одне завдання, діти отримують підказку для виконання наступного, що $є$ ефективним засобом мотивації до подальшого пізнання i дослідження (Рабчун, 2017, сс.6-7).

Однією з інноваційних форм взаємодії педагога і дітей $є$ «геокешинг». Ця технологія дозволяє зробити процес навчання цікавим, актуальним, особистіснозначущим, продуктивним, творчим.

Геокешинг - це захоплююча командна гра, в якій присутні: подорож, знаходження місця розташування заданих об'єктів, пошук інформації про об'єкти і відповідей на питання, розвиток допитливості та пізнавальної активності, уміння спілкуватися і знаходити в результаті спілкування потрібну інформацію, вирішувати проблему спільно (Рабчун, 2017, сс.6-7).

Головна особливість геокешинга - це те, що «схованки» створюються в місцях, які уявляють природний, історичний, культурний або географічний інтерес. 3 дітьми дошкільного віку використовуються тільки елементи цієї гри. У молодшому дошкільному віці гра проводиться з використанням готових схем 
та карт казок. Дітям старшого дошкільного віку можна запропонувати виготовити схему самим у спільній діяльності з дорослим (там само).

Сучасні дослідження та практичний досвід педагогів доводять, що одним із найактуальніших, найефективніших видів розвивальної гри є гра-стратегія.

Гра-стратегія - це складна, багатопланова діяльність, яка передбачає не тільки усвідомлення ігрового задуму, сюжетної лінії, але й уміння планувати свої дії, бачити кінцевий результат, дотримуватися плану і злагодженої роботи в команді (Гавриш, Іванова, 2018).

Особливістю гри є те, що в іiі основу покладено інтригу, реальну проблему, конкретну мету, для реалізації якої необхідно об'єднати зусилля. Гра не лімітована в часі, вона може тривати впродовж кількох днів, причому гравці повертаються до самого початку, змінюючи деякі обставини, розігруючи нові конструктивні способи розв'язання проблем, що виникають. Варіанти сюжетів гри: «Великий гаманець», «Пакуємо речі», «Будуємо дім», «Відкриваємо кав'ярню», «Зустрічаємо гостей», «Готуємо піцу» тощо.

У другій половині дня організовуються заходи 3 культурного дозвілля, орієнтовані на прояв дітьми самостійності і творчості в різних видах діяльності.

Дозвілля - це сукупність видів діяльності, які організовані дорослим для задоволення фізичних, інтелектуальних, соціальних і культурних потреб дітей: спортивне дозвілля (ігри, естафети, свята, розваги); інтелектуальне дозвілля (вікторини, турніри, лото, кросворди, ребуси, шаради); музичне та літературне дозвілля (музичний калейдоскоп, вечори загадок, зустрічі з цікавими людьми).

Можлива організація дозвілля відповідно до інтересів та уподобань дітей. У такому випадку дозвілля організовується як гурток.

Творча майстерня надає дітям можливість задовольнити свою потребу у творчій діяльності; створює умови для виявлення, задоволення й розвитку інтересів, здібностей і нахилів дітей. Майстерні можуть бути різнопланові за своєю тематикою та змістом, наприклад: заняття рукоділлям, залучення до народних промислів, оформлення художньої галереї, ігри та колекціонування.

Музично-театральна та літературна вітальня - це форма організації мистецької діяльності дітей, що передбачає слухання, обговорення, драматизацію літературних і музичних творів; співтворення дітей і дорослих, зустрічі з письменниками, композиторами, співаками, художниками, акторами.

Висновки і перспективи подальших розвідок. Питання сучасних форм організації освітнього процесу в закладах дошкільної освіти залишається актуальним. Сьогоднішні дошкільнята потребують цікавого, проблемноігрового, розвивального, особистісно-орієнтованого освітнього процесу, який забезпечується використанням сучасних форм, методів, технологій навчання та виховання. Тому кожен педагог повинен бути обізнаним 3 інноваціями в дошкільній освіті, розуміти та вміти застосувати їх у професійній діяльності. Доцільною є організації освітньої діяльності з дітьми дошкільного віку у формі педагогічного спілкування в колі, різних видів занять, освітніх ситуацій та подорожей, тематичних проєктів, прогулянок, екскурсій, колекціонування та експериментальної діяльності, ігор, культурного дозвілля, гурткової роботи, самостійної роботи дітей. Такі форми організації освітнього процесу в закладі дошкільної освіти мають величезний розвивальний потенціал, дошкільнята отримують можливість задовольнити властиву їм пізнавальну активність та допитливість, набувати та розширювали свої знання, розвивати дослідницькі навички, формувати уміння співпрацювати в колективі, опановувати систему 
моральних цінностей, отримувати життєвий соціальний досвід спілкування та доречної поведінки. Упровадження охарактеризованих форм організації освітнього процесу в практику роботи закладів дошкільної освіти забезпечує оновлення системи освіти та сприяє розвитку інноваційної особистості дитини. Перспективами подальших наукових розвідок може стати розробка методичних рекомендацій щодо використання сучасних форм організації освітнього процесу в закладах дошкільної освіти.

\section{СПИСОК ВИКОРИСТАНИХ ДЖЕРЕЛ}

Бєлєнька, Г. (2018). Сучасні підходи до організації життєдіяльності дітей у закладах дошкільної освіти. Дошкільне виховання, № 9. С. 2-6

Гавриш, Н. (2019). Прості речі для розвитку малечі: природні та побутові матеріали в життєдіяльності дітей. Дошкільне виховання, № 6 . С.9-13

Гавриш, Н., Іванова, А. (2018). Гра-стратегія, як засіб формування творчої особистості.

URL: https://slovyanochka.at.ua/publ/gra_strategija_jak_zasib_formuvannja_tvorchoji_osob istosti/1-1-0-15 [Дата останнього звернення: 05.10.2020].

Козак, Л. (2020). Сучасні форми організаџї освітнього процесу. Дитини: Освітня програма для дітей від двох до семи років / наук.кер.проєкту В. О. Огнев'юк; авт.кол.: Г.В. Бєлєнька [та ін.]; наук.ред. Г.В.Бєлєнька. К.: Київ.ун-т ім.Б.Грінченка. 440 с.

Козак, Л., Коваль В. (2020). Проєктна діяльність як засіб підготовки дитини до навчання у Новій українській школі. Педагогіка формування творчої особистості у вищій $і$ загальноосвітній школах. № 71, T. 1. С.127-131. DOI https://doi.org/10.32840/1992-5786.2020.71-1.22

Крутій, К. (2016). На зміну заняттю - освітні ситуації: збережемо найкраще і підемо далі. Дошкільне виховання, № 9. С. 6-10

Крутій, К., Грицишина, Т., Стеценко, І. (2017). Використання технології «освітня подорож» як засіб реалізації STREAM-освіти дошкільників. Навчання $i$ виховання обдарованої дитини, №2. C.43-48

Рабчун, Н. (2017). Геокешинг - це весело! Інноваційний проєкт 3 впровадження освітньої технології геокешинг, квест-геокешинг в роботу 3 дітьми дошкільного віку. Нетішин: 116 с.

Терещенко, I. (2019) Дослідники і колекціонери. Дошкільне виховання, № 10. C. $30-31$

\section{REFERENCES}

Bielienka, H. (2018). Suchasni pidkhody do orhanizatsii zhyttiediialnosti ditei u zakladakh doshkilnoi osvity.[Modern approaches to the organization of children's lives in preschool institutions]. Doshkilne vykhovannia, No 9. S. 2-6. [in Ukrainian]

Havrysh, N. (2019). Prosti rechi dlia rozvytku malechi: pryrodni ta pobutovi materialy v zhyttiediialnosti ditei. [Simple things for toddler development: natural and household materials in children's lives]. Doshkilne vykhovannia, No 6. S.9-13.[in Ukrainian]

Havrysh, N., Ivanova, A. (2018). Hra-stratehiia, yak zasib formuvannia tvorchoi osobystosti. [Game-strategy as a means of forming a creative personality.]. URL: https://slovyanochka.at.ua/publ/gra_strategija_jak_zasib_formuvannja_tvorchoji_osob istosti/1-1-0-15 [Data ostannoho zvernennia: 05.10.2020]. [in Ukrainian] 
Kozak, L. (2020). Suchasni formy orhanizatsii osvitnoho protsesu. [Modern forms of organization of the educational process.] Dytyny: Osvitnia prohrama dlia ditei vid dvokh do semy rokiv / nauk.ker.proiektu V.O. Ohneviuk; avt.kol.: H.V. Bielienka [ta in.]; nauk.red. H.V.Bielienka. K.: Kyiv.un-t im.B.Hrinchenka, 2020. 440 s. [in Ukrainian]

Kozak, L., Koval V. (2020). Proiektna diialnist yak zasib pidhotovky dytyny do navchannia u Novii ukrainskii shkoli. [Project activity as a means of preparing a child to study at the New Ukrainian School] Pedahohika formuvannia tvorchoi osobystosti $u$ vyshchii $i$ zahalnoosvitnii shkolakh. No 71, T. 1. S.127-131. DOI https://doi.org/10.32840/1992-5786.2020.71-1.22. [in Ukrainian]

Krutii, K. (2016). Na zminu zaniattiu - osvitni sytuatsii: zberezhemo naikrashche i pidemo dali.[In place of the lesson - educational situations: keep the best and move on]. Doshkilne vykhovannia, No 9. S.6-10. [in Ukrainian]

Krutii, K., Hrytsyshyna, T. \& Stetsenko, I. (2017). Vykorystannia tekhnolohii «osvitnia podorozh» yak zasib realizatsii STREAM-osvity doshkilnykiv. [ The use of "educational travel" technology as a means of implementing STREAM-education of preschoolers]. Navchannia $i$ vykhovannia obdarovanoi dytyny, No2. S.43-48. [in Ukrainian]

Rabchun, N. (2017). Heokeshynh - tse veselo! [Geocaching is fun!] Innovatsiinyi proekt z vprovadzhennia osvitnoi tekhnolohii heokeshynh, kvest-heokeshynh v robotu z ditmy doshkilnoho viku. Netishyn: $116 \mathrm{~s}$. [in Ukrainian]

Tereshchenko, I. (2019) Doslidnyky i kolektsionery. [Researchers and collectors] Doshkilne vykhovannia, No 10. S.30-31. [in Ukrainian]

\title{
MODERN FORMS OF THE EDUCATIONAL PROCESS IN PRESCHOOL EDUCATION INSTITUTIONS
}

\author{
Liudmyla Kozak \\ Doctor of Sciences (in Pedagogy, Associate Professor, \\ Professor at the Department of Preschool Education Senior, \\ Borys Grinchenko Kyiv University, \\ Kyiv, Ukraine, \\ ORCID: 0000-0002-4528-1905 \\ e-mail:l.kozak@kubg.edu.ua
}

\begin{abstract}
The article highlights the relevance of the use of modern forms of the educational process organization in preschool education institutions; It is established that the educational process in the conditions of preschool education is a holistic process of interaction between adults and children, which develops in time and space within a certain system and is aimed at achieving socially significant results - life competence acquisition, development of basic personality traits in various activities; it is proved that the modern educational process is characterized by integrativity, problem-play orientation, provides cognitive communication between educator and children, independence of children and personality-oriented approach of the teacher; the expediency of organizing educational activities with preschool children in the form of pedagogical communication in a circle, different types of classes, educational situations and travels, thematic projects, walks, excursions, research, games, group work, productive work, independent activities of children respectively to the tasks of physical, social, communicative, cognitive and artistic and aesthetic development is
\end{abstract}


emphasised; scientific researches concerning questions of application of modern forms of the educational process organization in preschool education establishments are analysed; the content of the concepts "educational process in the conditions of preschool education institution", "forms of educational process organization", "communication in a circle", "modern lesson", "educational situation", "educational trip", "project activity", "collecting" "experimentation", "quest", "geocaching", "games with free materials", "strategy game" are revealed; the peculiarities of modern forms of the educational process organization in preschool institutions are characterized; the most used forms of the organization of preschool children activity are defined; it was concluded that during specially organized educational and cognitive activities the teacher should help the child to obtain an age-appropriate amount of knowledge and practically acquire important skills, master the system of moral values, gain life social experience of communication and appropriate behaviour.

Key words: forms of organization of educational process, educational situation, educational trip, communication in a circle, project activity. collecting, experimenting, quest, geocaching, strategy game, games with free materials, circle, independent artistic activity.

Стаття надійшла до редакиії 07. 09. 2020 р. 